Jurnal Pemberdayaan: Publikasi Hasil Pengabdian kepada Masyarakat

Vol. 2, No. 1, April 2018, Hal. 15-19

ISSN: 2088 4559; e-ISSN: XXXX-XXXX

DOI:

\title{
TEKNIK BERCOCOK TANAM HIDROPONIK PADA LAHAN SEMPIT DI DUSUN TARUBAN WETAN, TUKSONO, SENTOLO, KULONPROGO
}

\author{
Salamah, $\mathrm{N}^{1}$, Riyanto $\mathrm{A}^{2}$ \\ Universitas Ahmad Dahlan Yogyakarta ${ }^{1,2}$ \\ Email: ninasalamah1996@ gmail.com ${ }^{1}$
}

\begin{abstract}
ABSTRAK
Permasalahan yang ada di masyarakat Dusun Taruban Wetan, Tuksono, Sentolo, Kulonprogo, Yogyakarta salah satunya adalah kurangnya pengetahuan masyarakat tentang cara bercocok tanam tanpa menggunakan media tanah dan pestisida di area yang seadanya. Maka program kerja KKN Reguler UAD difokuskan pada teknik bercocok tanam tanpa menggunakan media tanah dan pestisida (Hidroponik) pada area sempit. Program tersebut bertujuan untuk memberdayakan masyarakat dusun Taruban Wetan mengenai teknik bercocok tanam Hidroponik. Metode dari pelaksanaan program KKN ini meliputi: ceramah untuk meningkatkan pengetahuan masyarakat, penerangkan tentang teknik sederhana dan praktek secara langsung. Hasil pencapaian program pelatihan dari kegiatan $\mathrm{KKN}$ ini adalah: terciptanya kesadaran masyarakat tentang PHBS, peningkatan pengetahuan masyarakat mengenai teknik bercocok tanam Hidroponik, masyarakat dapat terampil menggunakan barang bekas menjadi media tanam Hidroponik, masyarakat dapat memanfaatkan area sempit sebagai tempat bercocok tanam Hidroponik
\end{abstract}

Kata kunci : pemberdayaan, taruban wetan, hidroponik, KKN UAD

\begin{abstract}
The problems that exist in Taruban Wetan Hamlet, Tuksono, Sentolo, Kulonprogo, Yogyakarta, one of which is the lack of public knowledge about how to grow crops without using soil media and pesticides in makeshift areas. So the UAD Regular KKN program is focused on farming techniques without using soil media and pesticides (Hydroponics) in narrow areas. The program aims to empower the community of Taruban Wetan hamlet about Hydroponic farming techniques. The methods of implementing this Community Service Program include: lectures to improve community knowledge, explain simple techniques and practice directly. The results of the achievement of the training program of the KKN activities are: the creation of public awareness about PHBS, increasing community knowledge about Hydroponic farming techniques, the community can be skilled in using used goods as a Hydroponic planting media, the community can use a narrow area as a Hydroponic planting place.
\end{abstract}

Keyword: Empowerment, Taruban Wetan, KKN UAD 


\section{PENDAHULUAN}

Dusun Taruban Wetan terletak di Desa Tuksono, Kecamatan Sentolo, Kabupaten Kulon Progo, Provinsi Daerah Istimewa Yogyakarta. Padukuhan Taruban Wetan ini termasuk salah satu sub unit kerja KKN Reguler LXV UAD tahun akademik 2017-2018. Taruban Wetan merupakan salah satu padukuhan dari 12 padukuhan di desa Tuksono, yang terletak di Barat Provinsi Daerah Istimewa Yogyakarta, batas wilayah Padukuhan Taruban Wetan adalah: batas sebelah utara adalah Dusun Bulak, batas sebelah selatan adalah Dusun Gunung Duk, batas sebelah timur adalah Dusun Krebet, batas sebelah barat yaitu sebagian Dusun Gunung Duk dan sebagian dusun Taruban Kulon. Pelaksanaan KKN regular dilaksanakan selama 30 hari.

Dusun Taruban Wetan ini memiliki 4 Rt dan 2 Rw yang sangat hidup rukun dan damai. Akses jalan Dusun Taruban Wetan cukup mudah dilalui oleh kendaraan darat baik roda dua maupun roda empat karena dekat dengan jalan raya yang menuju kecamatan sentolo. Sebagian besar masyarakat Dusun Taruban Wetan bermata percaharian sebagai petani sedangkan sisanya berprofesi sebagai wiraswasta, buruh bangunan, buruh pabrik, PNS, dan lain-lain.

Beberapa permasalahan yang ditemukan di Dusun Taruban Wetan adalah : 1) Kurangnya pengetahuan masyarakat mengenai teknik bercocok tanam Hidroponik, 2) Kurangnya pemanfaatan barang bekas oleh masyarakat menjadi media tanam Hidroponik, 3) Masih kurangnya kesadaran masyarakat tentang bahaya penggunaan pestisida pada tanaman, 4) Masyarakat kurang memanfaatkan lahan sempit sebagai tempat bercocok tanam Hidroponik.

Menurut (Lingga, 1999) Hidroponik berasal dari bahasa Latin yang terdiri dari kata hydro yang berarti air dan kata ponos yang berarti kerja. Jadi definisi hidroponik adalah pengerjaan atau pengelolaan air yang digunakan sebagai media tumbuh tanaman dan tempat akar tanaman mengambil unsur hara yang diperlukan. Umumnya media tanam yang digunakan bersifat poros, seperti pasir, arang sekam, batu apung, kerikil, rockwool. dengan kata lain Hidroponik merupakan teknik menanam dengan menggunakan media air tanpa menggunakan media tanah, sehingga teknik bercocok tanam hidroponik dapat dilakukan di lahan seadanya bahkan diteras maupun pekarangan rumah.

Peran masyarakat dalam pemanfaatan lahan sempit pada teknik bercocok tanam Hidroponik tidak lepas dari kesadaran masyarakat akan bahayanya penggunaan pestisida. Selain itu, masyarakat masih perlu diberi edukasi tentang pemanfaatan lahan. Berhasilnya program pengembangan teknik bercocok tanam hidroponik di Dusun Taruban Wetan tidak 
lepas dari kesediaan, semangat dan keinginan masyarakat dalam mengembangkan teknik bercocok tanam hidroponik. Dengan demikian keterampilan masyrakat dalam teknik bercocok tanampun lebih berkembang, bersih dan sehat. Akan tetapi, masyarakat juga perlu mengetahui bahwa tanaman yang baik untuk teknik hidroponik adalah sejenis sayuran dan buah-buahan yang berumur pendek seperti sawi, pakcoi, tomat, bawang, seledri dan lain-lain. Tanpa adanya peran masyarakat program teknik bercocok tanam hidroponik tidak akan maksimal. Dengan adanya program teknik bercocok tanam Hidroponik dapat meningkatkan kebiasaan hidup sehat masyarakat Dusun Taruban Wetan. Karena sayuran ataupun buahbuahan dari teknik bercocok tanam tersebut tidak mengandung bahan kimia seperti pupuk pestisida.

Masyarakat Dusun Taruban Wetan yang mayoritas bermata pencaharian petani juga dapat sekaligus mendukung dilakukannya teknik menanam hidroponik, sejatinya perihal tanam menanam bukanlah hal yang asing untuk dilakukan. Hanya saja, untuk bercocok tanam hidroponik tidak menggunakan media tanah melainkan menggunakan media air lengkap dengan air nutrisinya sebagai pengganti pupuk pestisida. Berdasarkan permasalah tersebut, maka tujuan program KKN Reguler UAD Ke-65 di Dusun Taruban Wetan adalah untuk memberdayakan masyarakat dusun Taruban Wetan mengenai teknik bercocok tanam tanpa menggunakan media tanah dan pestisida (Hidroponik) di lahan sempit.

\section{METODE}

\section{A. Alat dan Bahan}

Bahan yang digunakan pada pelatihan hidroponik ini adalah botol-botol bekas, pralon, Ban bekas, tanah, pupuk kompos dan berbagai barang bekas yang lain. Alat yang digunakan adalah gunting, pisau, dan alat-alat untuk bertanam.

\section{B. Jalannya Pelatihan}

Metode pelaksanaan program teknik bercocok tanam Hidroponik dalam mencapai tujuan memiliki tiga kategori yaitu, pengetahuan masyarakat, teknik sederhana dan praktek secara langsung. Ringkasan metode pelaksanaan beserta jam kerja efektif mahasiswa (JKEM) untuk program unggulan tersaji dalam tabel I. 
Tabel 1. Metode, Kegiatan, JKEM dan Keterlibatan masyarakat

\begin{tabular}{|l|l|l|l|c|}
\hline No. & Metode & Kegiatan & JKEM & $\begin{array}{c}\text { Jumlah } \\
\text { peserta yang } \\
\text { terlibat }\end{array}$ \\
\hline 1. & $\begin{array}{l}\text { Peningkatan Pengetahuan } \\
\text { masyarakat (ceramah) }\end{array}$ & $\begin{array}{l}\text { Menyelenggarakan } \\
\text { sosialisasi tanaman } \\
\text { hidroponik }\end{array}$ & $4 \times 50 \%$ & 27 \\
\hline 2. & $\begin{array}{l}\text { Teknik } \\
\text { (ceramah) }\end{array}$ & $\begin{array}{l}\text { Demonstrasi media } \\
\text { tanam hidroponik metode } \\
\text { wick }\end{array}$ & $2 \times 100 \%$ & 27 \\
\hline 3. & $\begin{array}{l}\text { Praktek langsung } \\
\text { (demonstrasi dan praktek) }\end{array}$ & $\begin{array}{l}\text { Masyarakat } \\
\text { mempraktekan teknik } \\
\text { menanam hidroponik }\end{array}$ & $2 \times 150 \%$ & 27 \\
\hline
\end{tabular}

\section{HASIL, PEMBAHASAN, DAN DAMPAK}

Program KKN UAD dalam pemberdayaan msyarakat Dusun Taruban Wetan dengan teknik bercocok tanam hidroponik menggunakan metode yang paling sederhana yang sangat cocok untuk pemula, yaitu metode wick. Metode wick merupakan teknik menanam Hidroponik yang paling paling sederhana dari semua jenis sistem hidroponik. Metode wick bisa dengan memanfaatkan barang bekas sehingga tidak menggunakan pompa atau listrik (Anonim, 2018).

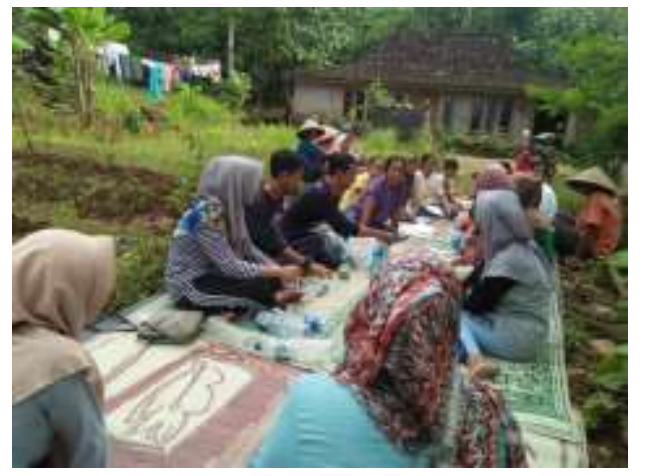

Gambar1. Sosialisasi dan demonstrasi Hidroponik

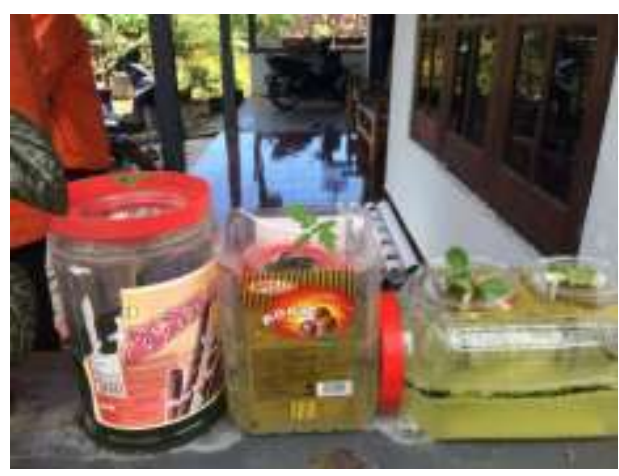

Gambar. 2 Hasil Hidroponik

Pelaksanaan program teknik bercocok tanam Hidroponik di Dusun Taruban melalui tiga tahap, yaitu sosialisai teknik menanam hidroponik dan demonstrasi teknik menanam hidroponik yang sekaligus dipraktekan langsung oleh warga masyarakat. hasil sosialisasi dan praktek secara langsung tersebut mendapatkan hasil yang cukup baik, dimana tanaman dengan teknik hidroponik tumbuh dengan subur dikediaman ibu Jiah selaku warga masyarakat Dusun Taruban Wetan. Sehingga program pemberdayaan masyrakat dengan 
teknik bercocok tanam Hidroponik cukup berhasil. Adapun tanaman yang yang digunakan adalah pakcoy dan tomat.

\section{SIMPULAN}

Program KKN Reguler UAD dalam memberdayakan masyarakat Dusun Taruban Wetan dalam program teknik bercocok tanam tanpa menggunakan media tanah dan pestisida (Hidroponik) pada lahan sempit telah berjalan dengan baik. Terdapat peningkatan pengetahuan dan keterampilan masayrakat di lokasi KKN.

\section{DAFTAR PUSTAKA}

Lingga, P. 1999. Hidroponik bercocok tanam tanpa tanah. Penebar Swadaya, Jakarta

Anonim. 2018. Cara membuat hidroponik dengan sumbu. http://www.tanamania.com/caramembuat-hidroponik-dengan-sumbu/\#z. Diakses tanggal 28 Februari 2018.

\section{UCAPAN TERIMAKASIH}

Terima kasih kepada seluruh masyarakat Dusun Taruban Wetan atas semangatnya dalam mengikuti program ini dan kepada Pak Kadus atas segala bantuan tempat dan peralatan yang digunakan. 